\title{
Against Bidimensional Supremacy in EU Constitutionalism
}

\author{
Vlad Perju*
}

(Received 06 July 2020; accepted 07 July 2020)

\begin{abstract}
Scholarly consensus sees EU supremacy as "necessarily bidimensional": the supranational dimension necessarily stands alongside the national dimension, which rejects the absolute and unconditional supremacy of EU law. I argue that this view of bidimensional supremacy is conceptually flawed and descriptively inaccurate. On the conceptual side, I identify the fallacy of symmetry (the idea that national and supranational perspectives on supremacy are similar in nature and equally reductionist), the fallacy of selection (the view that bidimensionalism alone can overcome what it perceives as an inevitable subjective bias in the choice between national and supranational supremacy claims), and the fallacy of construction (an originally shared popular sovereignty theory, which turns out to be riddled with biases that disrupt the equilibrium within the internally divided sovereign). On the interpretative side, I suggest that the empirical evidence in support of bidimensional supremacy is weaker than it is generally assumed. I then offer an interpretation of the PSPP judgment of the German Federal Constitutional Court, which holds a judgment of the Court of Justice of the European Union to be ultra vires, unlawful and thus non-binding. PSPP presents a problem of German origins and cast, rather than one stemming from the inner structure of EU constitutionalism. At most, PSPP represents a contingent, rather than necessary, and thus unexceptional instance of bidimensional supremacy.
\end{abstract}

Keywords: EU law; supremacy; German constitutionalism; constitutional theory; EU constitutionalism

\section{A. Introduction: The Bidimensionality Thesis}

Momentous as it might be, the conflict between the Court of Justice of the European Union (CJEU) and the German Federal Constitutional Court in the Weiss/PSPP judgements ${ }^{1}$ presents a challenge familiar to the European jurist. The juxtaposition of conflicting claims to final authority (national and supranational), compounded as ever by the lack of a supremacy clause in the EU Treaties, ${ }^{2}$ has long been a central theme in EU constitutionalism. It is true that the holding from

${ }^{*}$ Professor of Law, Boston College Law School and Director, Clough Center for the Study of Constitutional Democracy, Boston College.

${ }^{1}$ ECJ, Case C-493/17, Weiss and Others, ECLI:EU:C:2018:1000, Judgement of Dec. 11, 2018.; Bundesverfassungsgericht [BVerfG] [Federal Constitutional Court], Case No. 2 BvR 859/15 (May 5, 2020), http://www.bverfg.de/e/rs20200505_ 2bvr085915en.html [hereinafter PSPP].

${ }^{2}$ The closest the Lisbon Treaty comes to such a statement is, of course, Declaration 17. It remains a somewhat open question what precise role a stronger provision would have. In the admittedly different context of the UN Charter, Article 103 has hardly put an end to debates about supremacy. For analysis, see Rain Liivoja, The Scope of the Supremacy Clause of the United Nations Charter, 57 INT'L \& COMP. L.Q. 583 (2008). The reason has to do with the place of a supremacy clause within the overall legal architecture. In the context of the US Constitution, for example, Hamilton argued that the Supremacy Clause

(C) The Author(s), 2020. Published by Cambridge University Press on behalf of the German Law Journal. This is an Open Access article, distributed under the terms of the Creative Commons Attribution licence (http://creativecommons.org/licenses/by/4.0/), which permits unrestricted re-use, distribution, and reproduction in any medium, provided the original work is properly cited. 
Karlsruhe, that the CJEU exceeded its mandate by the specific manner in which it confirmed the legality of the so-called quantitative easing measures in the form securities purchases by the European Central Bank under its Public Sector Purchase Program (PSPP), escalates quite dramatically the stakes of the constitutional conflict. But the bidimensionality thesis, long the answer (of sorts) to the conundrum of constitutional conflict in the EU, will readily offer its interpretative framework to make sense of this clash.

The bidimensionality thesis holds that EU supremacy has necessarily more than one dimension. The first dimension belongs to the supranational level. It is the dimension expounded by the CJEU in a largely consistent, if increasingly complex, ${ }^{3}$ line of cases running from the early Costa ${ }^{4}$ through Simmenthal ${ }^{5}$ and on present-day iterations. ${ }^{6}$ The CJEU's sharply-worded press release following Karlsruhe's open challenge in PSPP spells out some of the core elements of supremacy from the supranational perspective: The absolute and unconditional primacy of EU law over national law, the CJEU's exclusive jurisdiction to invalidate EU secondary legislation, and the binding effect that CJEU judgments have on national referring courts. ${ }^{7}$

By itself, however, the supranational dimension is incomplete. From the bidimensional supremacy perspective, only the cooperation or acceptance of national constitutional guardians gives EU law "an impact on legal reality." "The second dimension of EU supremacy is therefore national. The "full reception" of EU law "depends on its incorporation into the constitutional orders of the Member States and its affirmation by their supreme courts." 9 While the CJEU and national apex courts both claim ultimate authority, neither claim by itself captures the complex nature of constitutional authority within the EU; only both perspectives, in tandem, do.

The bidimensionality thesis has two versions. The first, weak version stipulates that there are two different perspectives - the CJEU's and that of national apex or constitutional courts-on the issue of final authority as between national and supranational norms. This claim is correct but,

is only "declaratory of a truth which would have resulted by necessity and unavoidable implication from the very fact of constituting a federal government." The FedERALIST No. 33, 196 (Robert Scogliano ed., 2000). The arc of American federalism shows that to have been wishful thinking. Far from an ornament, the Supremacy Clause has become "the epicenter of the constitutional structure created by the Founders." See Bradford Clark, Federal Lawmaking and the Role of Structure in Constitutional Interpretation, 96 CAL. L. REV. 699, 724 (2008).

${ }^{3} \mathrm{As}$ EU doctrine matured, supremacy claims have come into conflict with other fundamental principles of the EU legal order such legal certainty, res judicata or environmental protection. For a recent case, see ECJ, Case C-379/15, Association France Nature Environnement v. Premier ministre and Ministre de l'Écologie, du Développement durable et de l'Énergie, ECLI:EU:C:2016:603, Judgment of July 28, 2016.

${ }^{4}$ Case C-6/64, Costa v. ENEL, 1964 E.C.R. 585 (1964) [hereinafter Costa]. Costa was not the first time the European judges adopted that interpretation. See, e.g., Case 6/60, Humblet, 1960 ECR 559 at 569 (1960) (holding that the provisions of the ECSC Treaty "have the force of law in the Member States following their ratification and [... ] take precedence over national law"). Some scholars see in Humblet the basis of the supremacy doctrine, prior to the Treaty of Rome. See René Barents, The Precedence of EU Law from the Perspective of Constitutional Pluralism, 5 EUR. CONST. L. REV. 431 (2009). This interpretation, however, removes the all-important holding in Van Gend from the lineage of supremacy. In reality, supremacy becomes a statement of a very different type once autonomy has been set in place, and the two doctrines can function like the double helix of European constitutionalism. Humblet's shallow take on supremacy, compared to Costa's, is thus unsurprising.

${ }^{5}$ Case C-106/77, Amministrazione delle Finanze dello Stato v Simmenthal SpA, 1978 E.C.R. 629. For a comprehensive recent study, see Michael Dougan, Primacy and the Remedy of Disapplication, 56 Common MKt. L. Rev. 1459 (2019).

${ }^{6}$ See Association France Nature Environnement, Case C-379/15.

${ }^{7}$ Court of Justice of the European Union, Press release following the judgment of the German Constitutional Court of 5 May 2020, https://curia.europa.eu/jcms/upload/docs/application/pdf/2020-05/cp200058en.pdf (last accessed June 6, 2020).

${ }^{8}$ Bruno de Witte, Direct Effect, Primacy and the Nature of the European Legal Order, in THE EvoluTION OF EU LAW 351 (Grainne de Burca \& Paul P. Craig eds., 2011) ("There is a second dimension to the [primacy] matter, which is decisive for determining whether the Court's doctrines have an impact on legal reality: the attitude of national courts and other institutions."). See also Karen Alter, The CJEU's PolitiCal Power 258-259 (1996) (“To put it bluntly, the ECJ can say whatever it wants, the real question is why anyone should heed it."); Joseph H.H. Weiler, Europe's Constitutional Sonderweg, in European Constitutionalism BeyOND the STATE 13 (2003) ("both in fact and in law, ultimate authority still rests in national constitutional orders which sanction supremacy, define its parameters, and typically place limitations on it.”).

${ }^{9}$ De Witte, supra note 8. 
without more, perfectly trite. All legal norms can be approached from "at least one other possible point of view." 10 A tax norm can be seen from the perspective of the tax authority and of the taxpayer; for traffic regulations, there is the standpoint of the traffic officer and of the driver; or, in a federal structure, that of the federal government and of the states, and so on. But, at least assuming overall legal stability, the question is not whether additional perspectives are available but if, when and for what purpose such perspectives are legally relevant. Approaching the tax code from the standpoint of the random tax evader illuminates neither the validity nor meaning of the tax norm. A municipal city clerk who, in defiance of applicable law, refuses to issue marriage licenses to same-sex couples does not pose an internal challenge to the validity of the legal norm; her act is simply one of lawbreaking. Similarly, in a federal system, the perspective of a norm that originates from the federal center can always be supplemented by the perspective of its constituting units. The federal regulation is bidimensional in this weak sense. But the perspective of addressee states is hardly relevant for understanding the center's prerogatives. The Saxony or Californian perspective on a particular federal regulation may be 'available'; yet the structure of German or US federalism subsumes those perspectives to that of the federal government, and makes the latter determinant for the purpose of norm-creation, interpretation and enforcement.

The bidimensional thesis as applied to EU supremacy makes a different and more assertive claim. In this second and stronger version, the reception into national law of the CJEU's supremacy doctrine is said to be not exogenous but, in a sense, constitutive of the doctrine itself. EU supremacy is "necessarily bidimensional" 11 in that it is co-constituted by two perspectives, each originating from within legal orders that can and sometimes do make mutually incompatible claims. According to this account, the CJEU's supremacy holdings stand neither higher nor lower but alongside and on an equal plane with the doctrines of national courts that incorporate-or not - Costa and its progenies into the constitutional orders of the several member states. ${ }^{12}$

Distinguishing between the two versions of the bidimensionality thesis would be less consequential if national constitutional orders uniformly accepted Costa as prevailing authority and shaped their internal doctrinal architecture accordingly. In that case, the necessitarian version would have little if any practical effect as it would eventually fold into the weak version of bidimensionalism. ${ }^{13}$ The real bite of the strong version of the thesis comes from the fact, or rather the assertion, that supremacy claims clash. Its defenders offer up a canon of judgments of national supreme/constitutional courts-including Semoules, ${ }^{14}$ Solange, ${ }^{15}$ Cohn-Bendit,${ }^{16}$ controlimiti,${ }^{17}$

\footnotetext{
${ }^{10}$ Neil MacCormick, Beyond the Sovereign State, 56 Modern L. REv. 1, 4 (1993).

${ }^{11}$ Joseph Weiler, The Community System: The Dual Character of Supranationalism, 1 YEARBOOK EuR. L. 267,275 (1981) (italics added for emphasis).

${ }^{12}$ See Neil MacCormick, Questioning Sovereignty 111 (1999) (“Once we have established this doctrine of the supremacy of Community law, however, the question inevitably to be posed is whether there is any need at all for an elaborate theory about interaction of distinct systems. If system X enjoys supremacy over system $\mathrm{Y}$, why trouble to have a theory about separate systems, rather than a theory which acknowledges the fact that Y belongs to X as subsystem of it?"); Neil MacCormick, The Maastricht Urteil: Sovereignty Now, 1 Eur. L.J. 259 (1995).

${ }^{13} \mathrm{Paul}$ Craig has pointed out that challenges to supremacy exist only when issues of Kompetenz-Kompetenz arise and not where the allocation of competencies to the European Union is beyond dispute. See Paul Craig, National Courts and Community Law, in Governing Europe 33-34 (Jack Hayward \& Anand Meron eds., 2003). This may be correct but since the nature of the Kompeten $z$ that Member states claim to have retained (respect for human rights, preservation of democracy, protection of identity) is more qualitative than sectorial, its irreducibly open textured nature would give member states the power to decide on the existence of a constitutional conflict and thus revisit at will previous recognition of EU supremacy. Recognition that lasts only until and unless member states have a substantive reason to challenge it is hardly the kind of recognition that Costa entails.

${ }^{14}$ Conseil d'Etat, Syndicat général de fabricants de semoules de France, C.M.L.R. 395 (1970).

${ }^{15}$ Bundesverfassungsgericht [BVerfG] [Federal Constitutional Court] May 29, 1974, 37 ENTSCHEIDUNGEN DES Bundesverfassungsgerichts [BVerfGE] 271, 285 [hereinafter Solange I].

${ }^{16} \mathrm{CE}$ Ass., Dec. 22, 1978, Case Ministre de l'intérieur c. Cohn-Bendit, Rec. 524 (Fr.).

${ }^{17}$ Corte Constituzionale, Dec. 17, 1973, n. 183, 2 C.M.L.R. 372 (1974).
} 
Maastricht ${ }^{18}$ and Lisbon, ${ }^{19}$ the Polish Accession Judgment,${ }^{20}$ Landtová, ${ }^{21}$ Ajos,${ }^{22}$ and now the allimportant $P S P P$ - as evidence of national resistance to the CJEU's absolute and unconditional claim of the Treaty's primacy over national law. National judges deem their domestic constitutions as having "precedence of binding force and precedence of application"23 over EU law. The outcome of this clash is a "bidirectional flow"24 of constitutional authority in the EU.

This Article challenges the strong version of the bidimensional thesis. Its main part identifies four fallacies, some conceptual-the fallacies of symmetry, selection, and construction-and others empirical — the fallacy of interpretation-. I should point out from the outset that my emphasis here is not on instrumental reasons for rejecting bidimensionalism, important though those reasons are. ${ }^{25}$ While bidimensionalism is inadequate to a political climate such as today's authoritarian backsliding at the hands of populist governments, casting the challenge solely on instrumental grounds risks portraying bidimensionalism as an otherwise sound constitutional theory that suddenly fell upon inauspicious political times. Its flaws, I argue, reach far deeper. The study of the fallacies of the bidimensional thesis sets the stage for a reflection in the last part of this Article on the PSPP judgment. PSPP presents a problem of essentially German origins and cast, rather than one stemming from the inner structure of EU constitutionalism. Approaching PSPP from this perspective does not downplay the perils this judgment poses to European integration. If anything, this interpretation reveals the magnitude of the challenges ahead. EU constitutionalism must disenthrall itself from the bane of identitarian legalism that pervades German constitutional thought. How such separation could take place remains very much an open question. But whatever else it would entail, such a move certainly requires the demise of the bidimensional thesis in favor of a hierarchical, if complex, and unidimensional supremacy of EU law over national legal orders.

\section{B. The Fallacies of Bidimensional Supremacy}

The bidimensional approach grows out of an impatience with what its defenders see as the insulated and relentlessly self-referential legal point of view. Such impatience has long informed critiques of legalism mounted by economists, historians, and political theorists. ${ }^{26}$ But the reaction to this seeming abyss between rigid law and flexible, daring political experimentation has also been internalized into legal thought. In the context of EU constitutionalism, Neil MacCormick created the label "mononuclear"27 and affixed it to reductionist legal perspectives, both national and supranational.

\footnotetext{
${ }^{18}$ Bundesverfassungsgericht [BVerfG] [Federal Constitutional Court] 12 October 1993, 89 ENTSCHEIDUNGEN DES Bundesverfassungsgerichts [BVerfGE] 155; Case 2134/92, Brunner v. The European Union Treaty, 1 C.M.L.R. 57 (1994).

${ }^{19}$ Bundesverfassungsgericht [BVerfG] [Federal Constitutional Court] June 30, 2009, 123 ENTSCHEIDUNGEN DES BundeSVERFASSUNGSGERICHTS [BVerfGE] 267 [hereinafter Lisbon Judgement].

${ }^{20}$ Trybunał Konstytucyjny [TK] [Constitutional Tribunal] May 11, 2005, Case No. 18/04 (Pol.) [hereinafter Accession Treaty].

${ }^{21}$ Nález Ústavního soudu ze dne 31.01.2012 (ÚS) [Judgment of Constitutional Court of Jan. 31, 2012], sp.zn Pl. ÚS 5/12 (Czech.).

${ }^{22}$ Danish Constitutional Court Case no. 15/2014 Dansk Industri (DI) acting for Ajos A/S v. Estate of A (relating to CJEU, Case C-441/14 Dansk Industri, acting on behalf of Ajos A/S v. Estate of Karsten Eigil Rasmussen).

${ }^{23} \mathrm{TK}$, Case $18 / 04$ at para 11.

${ }^{24}$ Joseph H.H. Weiler \& Joel P. Trachtman, European Constitutionalism and Its Discontents, 17 Nw. J. INT'L L. \& BUs. 354, 374 (1997) (describing "[t]he flow of authority" as "bidirectional").

${ }^{25}$ See, e.g., R. Daniel Kelemen, On the Unsustainability of Constitutional Pluralism: European Supremacy and the Survival of the Eurozone, 23 MaAstricht J. Europ. \& Comp. L. 136 (2016); R. Daniel Kelemen \& Laurent Pech, The Uses and Abuses of Constitutional Pluralism: Undermining the Rule of Law in the Name of Constitutional Identity in Hungary and Poland, 21 Cambridge Yearbook Eur. Leg. Stud. 59 (2019).

${ }^{26}$ One early study, piercing yet nuanced, is JUDITH SHKLAR, LEGALISM (1964).

${ }^{27}$ MacCormick, supra note 10 , at 5 .
} 
Suppose you thought the engine of European integration is the member states defining their preferences in issue-specific policies and then engaging in international cooperation through bargaining based on the asymmetrical interdependence among their respective national preferences. $^{28}$ Supranational structures created through such processes of cooperation and competition reflect how domestic social groups, each formed around specific policies and within the particular institutional and political context of each state, would strategically pressure their respective governments into joining transnational networks whose effects, in terms of both domestic redistribution and institutional disruption, would be beneficial to the social group. While these processes of functional interdependence do have common features, what stands out is the contextual and fluid nature of their complex bargaining. It is this complexity and the need for constant adaptation that, in this view, explains the resilience of states vis-à-vis supranational authority, without however challenging the important role of the latter, which possess a wide array of tools, both formal and informal, to institutionalize transnational agreements. ${ }^{29}$

Take now this complex view of policy formation and try to map it onto formal legal discourse. The result is a striking mismatch. Rather than operating with an account of responsive legal authority that can be carefully calibrated to the context-sensitive policy dynamics of supranational cooperation, legal institutions seem stuck in rigid canons of ex ante allocations of authority. The legal mindset, at both national and supranational levels, is locked into a narrow outlook dictated by nothing other than its own restricting logic. Can anything close this gap?

There are two possible solutions. One is to assume that legal rationality is unchangeably reductionist, give up on law as a site of emancipation through experimentation and set out to search for answers elsewhere. If law — national, supranational, international—is forever stuck in tedious formalism, it should at least be contained so as not to arrest political and social experimentation. A second solution is to open legal rationality from within. Law, in this view, must enhance its adaptive capacities by overcoming the inherent limitations of its narrow perspectives. The strong, necessitarian view of bidimensionality takes this latter route. While placing itself firmly within law, it seeks to open up the legal perspective. It calls for a novel account of legal authority, which reflects a mindset of accommodation and compromise and which softens and fundamentally transforms the interaction of legal standpoints heretofore prone to tout their absolute and unconditional authority.

While in my view correct in its fundamental choice to work within law, rather than outside of it, the bidimensional thesis in the context of EU legal integration falls prey to four fallacies. The first is the fallacy of symmetry. Its search for a composite perspective mistakenly assumes that the different perspectives - national and supranational - are similarly reductionist. In reality, the two types of perspectives could not be more different. Since the EU supranational perspective, properly understood, is already multidimensional in nature, an approach that focuses squarely on its own integrative potential provides all the benefits of the bidimensional thesis without its many shortcomings. The second is the fallacy of selection. This fallacy reveals itself in how bidimensionalism's defiance of the choice between supposedly one-sided national and supranational perspectives ends up replicating precisely the mononuclearism that it had set out to overcome. Put more directly, the bidimensional approach fails to avoid and in fact replicates the reductionism and narrowness for which it blames exclusively national and exclusively supranational perspectives. The third is the fallacy of construction. Its dismissal of hierarchical supremacy leaves bidimensionalism contorting itself in a theory of constituent power where individuals are dual sovereigns in their concomitant capacity of members of both nation states and the supranational polity. Yet, built-in imbalances between the two perspectives become breaking points when this

\footnotetext{
${ }^{28}$ I'm describing here liberal inter-governmentalism, still said to constitute, at least by the lights of its leading authors, the baseline theory of European integration. See Andrew Moravcsik, Preferences, Power and Institutions in 21st-century Europe, 56 J. Common Mкт. STUD. 1648, 1649 (2018).

${ }^{29} I d$.
} 
account is put to the test of political reality. It would better service that reality if, instead of theorizing dualism, the theory of popular sovereignty would offer an assertive and creative account of supranational constituent power. The fourth fallacy is that of interpretation. The empirical support for the bidimensionality thesis is rarely if ever called into question. ${ }^{30}$ Yet it is far from indisputable. I contrast a continuity model of national rejection of absolute EU supremacy with a discontinuity model that points out disruptions in the approaches over time of national courts. According to this latter interpretation, national challenges to EU supremacy in cases such as PSPP reflect a contingent, rather than necessary, dimension and thus support a weak and largely unexceptional case for bidimensional supremacy.

\section{The Fallacy of Symmetry}

The bidimensional approach presents itself as an alternative to legal perspectives whose reliance on sovereignty renders them inherently hierarchical and reductionist. Neil MacCormick chides the "compulsion to regard 'sovereignty', or even a hierarchical relationship of super-ordination and subordination, as necessary to our understanding of legal order in the complex interaction of overlapping legalities." ${ }^{11}$ In this view, any perspective shaped by sovereignty forces ready-made answers to problems whose rich complexity defy linear legal rationalities. When supremacy claims clash, the view from sovereignty posits the need to select one of the claims on offer while disregarding the availability and insights embedded in the perspective of the claim thereby rejected. Sovereignty becomes the medium through which the "dangerous megalomania" 32 inherited from the age of absolute monarchies with its emphasis on singular and indivisible authority stifles governance in a complex polity such as the EU.

It is easy to find evidence of such purportedly reductionist holdings in national and supranational claims to supremacy. At the European level, the Treaty's normative echo chamber is on full display in the CJEU's reaction to the PPSP judgment. The public statement reiterates that the CJEU deems its jurisdiction to invalidate EU legislation exclusive. In its view, national authorities, including courts, are Treaty-bound to apply EU law. National referring courts lack authority to hold that a CJEU judgment "constitutes an ultra vires act and thus has no binding effect" 33 within the jurisdiction they control. Thus, according to the Luxembourg court, the Treaty's authority is content-independent, in the sense that duties do not depend on their addressees finding "the interpretation undertaken by the CJEU ... comprehensible from a methodological perspective." 34

Conversely, a similarly exclusivist logic also underpins domestic claims to authority. National constitutions set up complex mechanisms through which each member state delegates powers to EU institutions. Those powers are to be exercised in common at the supranational level, subject to conditions and limitations imposed expressly or implicitly to guarantee consistency with the nature of the delegation of sovereign rights. ${ }^{35}$ As the Warsaw Trybunat Konstytucyjny put it, the national constitution has "precedence of binding force and precedence of application" 36 over EU law. In the hands of national courts, the ultra vires doctrine preserves the ability of each

\footnotetext{
${ }^{30} \mathrm{Neil}$ Walker is surely right to point out that acceptance of the empirical analysis offered by constitutional pluralism pushes the normative analysis in the direction of pluralism. See Neil Walker, Constitutional Pluralism Revisited, 22 EUR. L.J. 333-355, 346 (fn. 46).

${ }^{31}$ MacCormick, supra note 10 , at 10.

${ }^{32}$ Hannah Arendt, Nation-State and Democracy, in Thinking without BANISTERS: EsSAYs IN UNDERSTANDING 1953-1975, 261 (Jerome Kohn ed., 2018).

${ }^{33}$ PPSP at para 119.

${ }^{34}$ PPSP at para 153.

${ }^{35}$ For an account, and critique, of delegation, see Alexander Somek, Delegation and Authority: Authoritarian Liberalism Today, 21 Eur. L.J. 340 (2015).

${ }^{36} \mathrm{TK}$, Case $18 / 04$ at 11 .
} 
member state "to continue functioning as a sovereign and democratic state." ${ }^{37}$ And since, in the words of the German Federal Constitutional Court, "the primacy [of EU law] ... only applies by virtue and in the context of the constitutional empowerment," 38 national authorities have a duty under their national constitutions to enforce the principle of conferral and specifically to prevent EU institutions, such as the European Central Bank in the case of the PPSP, from creating new competences for itself. ${ }^{39}$

The binary logic of sovereignty demands a choice between these incompatible claims. But whichever of the two comes on top, the outcome will be as partial and one-sided as the options on offer. The supranational option "overwhelms" 40 the national legal orders, which become subsumed to EU commands. The alternative places national constitutions over the Treaty, thus denying the latter's singularity as a source of law and treats the EU as if it were one among a garden variety of international organizations. In this either/or world, each of the two perspectives is insulated from the other and is thus deemed inadequate. The juristic challenge is to overcome the binary choice and reject the inherent reductionism that characterizes hierarchical approaches. That challenge is to construct an encompassing legal standpoint.

Note, however, a revealing tension in the very construction of the choice between supposedly symmetrical options. The challenge is here presented as one of overcoming sovereignty, a framework of authority that makes each perspective-national and supranational - inherently mononuclear. But the description of each legal perspective as inherently mononuclear is true only from a standpoint that itself assumes the existence of sovereignty. For the claim that national and European legal systems are similar in nature is tenable only from the perspective, itself mononuclear, that reduces each legal order to its underlying logic of sovereignty. Sovereignty, it turns out, informs the very description of the situation that supposedly requires its demise.

This problem is deeper than a mere inconsistency. It is, rather, a problem of conceptualization. The bidimensional approach mistakenly interprets the substance of a doctrinal claim (supremacy) to reveal the normative makeup (reductionist) of the national and supranational legal orders wherein these claims originate. But why deem the internal legal perspective of supranational Europe similar in nature to that of the EU's constitutive member states? Just as EU policies aim to integrate by overcoming restrictive nationalism, so presumably its law seeks to overcome the many forms of reductionism on which that nationalism depends for its stability. The telos of European constitutionalism is precisely not to replicate the exclusionary perspective of the nationstates. The nature of the supranational legal order thus seems emphatically different from that of national legal orders. ${ }^{41}$

It remains, of course, open to interpretation how successful has been the supranational project of creating a legal order unaffected by the kind of partiality and reductionism that characterized the legal systems of the member states. Put differently, one can debate if the CJEU has met the burden of developing the necessary jurisprudential edifice. Neither success nor failure can simply

\footnotetext{
${ }^{37} I d$. at 8 .

${ }^{38}$ Lisbon Judgement at 348-349. Cf. English translation, at para. 240.

${ }^{39}$ PPSP at para 102 . One prominent mechanism is the ultra vires doctrine. It is worth recalling, however, that, in principle, the ultra vires doctrine can be deployed in both directions. See Amedeo Arena, How European Law BeCAme Supreme: The MAKING OF CosTA V. ENEL, Jean Monnet Working Paper 05/18, at 14 (mentioning the view of the plaintiff in Costa that "by encroaching upon an area where sovereign powers had been surrendered to the EEC, the Italian legislature had acted ultra vires") (available at https://jeanmonnetprogram.org/wp-content/uploads/JMWP-05-Amedeo-Arena.pdf).

${ }^{40}$ JÜrgen Habermas, The Lure of TeChnOcracy 40 (2015).

${ }^{41}$ One could describe it as a "molecular." See Peter Mair, Ruling the Void: The Hollowing Out of Western DEMOCRACY 139 n. 23 (2013) (defending a "molecular" theory of Europe where the mix between the national and supranational are impossible to tell apart.) I read Neil Walker's reference to particularism, as preferable to monism, as searching for a similar concept. See Walker, supra note 30, at 337, n. 12 (2016). This legal perspective rejects separatism between the municipal, international and supranational distinctions, and a claim, or at least an attempt, to integrate organically the different strands. For an instance of such organic integration, see Daniel Sarmiento, Case Note: Reinforcing the (domestic) constitutional protection of primacy of EU Law, 50 COMMON MKT. L. REV. 875, 882 (2013).
} 
be assumed. One must, rather, make the affirmative case for either assessment. But these are conclusions that require argument. They cannot be introduced in the form of stipulation about the symmetrical nature of the national and supranational legal orders, upon which an entire jurisprudential edifice self-servingly rests.

\section{The Fallacy of Selection}

Return now to the choice itself between the national and the supranational supremacy claims. The necessitarian claim of bidimensional supremacy posits a lack of an objective basis on which such a choice can be made. It portrays the choice as inevitably a matter of "ideological preference rather than analytical refinement." ${ }^{2}$ The choice between the two mononuclear perspectives is, in this view, not dictated by criteria internal to the choice itself, but rather by exogenous considerations.

But what of bidimensional supremacy itself? Can this supposedly integrative approach, which "embraces the possibility of acknowledging differences of perspectives, differences of points of view" "33, escape the inherent subjectivity of sovereignty-centered perspectives? By its own account, it does. Its perspective, it claims, is "independent and disinterested." ${ }^{4}$ The bidimensional thesis claims to have found the Archimedean ground from which it can construct an account of European constitutionalism that is neither biased nor inherently reductionist. How so?

One possibility is that its objective basis tracks its comprehensive nature. Because it is integrative, rather than partial, the bidimensional thesis rejects both the subjectivity of the exclusively national and that of the exclusively supranational. The fair integration of all the different perspectives cannot be faulted for preferential treatment of any one view. However, this solution is, even under the best of circumstances, insufficient. For the real question is not if comprehensiveness is objective and thus preferable to reductionism. It is, rather, where should comprehensiveness be located. Does comprehensiveness result solely from the combination of national and European standpoints, as the bidimensional approach assumes? Or does it result from making the European internal standpoint as broad, integrative and encompassing as possible through a fusion of national perspectives and a corresponding filtering of the result through the normative commitments that are stipulated and institutionalized in the Treaty?

A brief excursus into the intellectual origins of the bidimensionality thesis is instructive on this point. Writing just a few months before the fall of the Berlin Wall, Neil MacCormick argued that European politics was overly atomized and pervaded by a vision of dislocated individuals driven to interact with one another through one-off voluntary agreements. That, he feared, may act as a model of market exchanges but it could neither create nor sustain the production and reproduction of social meaning in late twentieth-century European democracies. A fuller life would be possible only when politics is brought back in. But the possibility of politics, or at least the kind of politics MacCormick had in mind, depends on social bonds that require a sense of sharing and togetherness for which a common language, the cultural memory of shared traditions, and, yes, proximity are indispensable. Since supranational integration had emasculated this politics, refurbishing institutionalized forms of social solidarity requires integrating back into states these "cultural communities endowed with political relevance" 45 - that is, nations - and thus saving them from the effect of voracious market forces. Intellectually, it would require defending a moderatethat is, non-mystical—version of nationalism. ${ }^{46}$

\footnotetext{
${ }^{42}$ Walker, supra note 30, at 338. Professor Walker then goes on to describe the situation "absent any objective basis to choose between either of the situated particularisms."). See also Barents, supra note 4, at 431 (arguing that the choice between the national and European orders is "often based on implicit ideological premises and political preferences").

${ }^{43}$ MacCormick, supra note 10 , at 6 .

${ }^{44} \mathrm{Id}$.

${ }^{45} I$ d. at 16. See also ERNEST GELLNER, NATIONS AND NATIONALISM 4 (1993) ("Nationalism is a political principle that maintains that the similarity of culture is the basic social bond.").

${ }^{46}$ MacCormick, supra note 10 , at 16.
} 
How, one might ask, does MacCormick's challenge to the "hostile dismissiveness" of nationalism dovetail with the supposedly independent and disinterested standpoint from which to overcome the binary choice between a national or European perspective? ${ }^{47}$ Without a European demos, there will be no democratic rock upon which that supranational integration can independently rest unless the project of national self-government is carried forward into the very heart of European nationalism. Indeed, the centrality of the demos makes the tilt toward nation states so prominent that, were it possible to submit European constitutional authority to the idiosyncrasies and affectations of each national legal order, one would have to wonder why the bidimensional approach does not go all the way in the other direction and subsume the supranational project to the nation-states? ${ }^{48}$

The need for balance in the bidimensional thesis receives a justification (of sorts) in that close coordination within an integrated Europe is itself benefic to the self-governing peoples of the Member States. As Joseph Weiler writes, "it is a remarkable instance of civic tolerance to accept being bound by precepts articulated not by "my people" but by a community composed of distinct political communities: a people, if you wish, of others." 49 There is supposedly no room for arrogance in this political construct where the people of each Member State, which remain committed to their self-government, are invited-rather than forced-to obey. In this normative vision of Europe, the national standpoint does not dissolve into the European standpoint, which remains important in its own right. The resulting equilibrium - "transcend[ing] the sovereign state without dissolving the nation" 50 _remains fragile.

It should be vigorously disputed whether this view captures the critical ingredients of the success, such as it has been, of European integration. Suffice it to say at this stage that the challenge would contrast the vision of integration as coordination with a vision of integration as unification, or coordination plus. ${ }^{51}$ But for now, merely spelling out the vision behind the bidimensionality thesis shows the latter as hardly detached from politics and ideology. Despite its claim to the contrary, bidimensional supremacy is firmly grounded on a particular political and ideological project of European constitutionalism. It is neither objective nor disinterested. Rather, it is merely one constitutional theory owing its orientation to deeper normative visions.

\section{The Fallacy of Construction}

Normative visions, deep or shallow, must submit themselves to the discipline of constitutionalism. They must, at the very least, offer accounts of the origin and nature of political authority as well as

\footnotetext{
${ }^{47} \mathrm{His}$ own answer to this important question drifts, quite unhelpfully, towards high abstraction. Id. at 17 (arguing for an institutional arrangement that would entail a "diffusion of political power centers as well as of the legal authorities," and "it would depend on a high degree of relatively willing co-operation and a relatively low degree of coercion in its direct and naked forms.").

${ }^{48}$ Some theorists, of course, do go there. See Andrew Moravcsik, The European Constitutional Compromise and the Neofunctionalist Legacy, 12 J. EUR. PUB. POL'Y 349 (2005).

${ }^{49}$ Weiler, supra note 8.

${ }^{50}$ Neil MacCormick, Is Nationalism Philosophically Credible?, in Issues of SELF-Determination 18 (William Twining ed., 1991).

${ }^{51}$ One such example of the form of argument I have in mind comes from the Granital judgment of the Italian Constitutional Court. In that case, the Italian court posited that the Community legal order and the internal legal order are to be considered as "two separate but coordinated systems." But the court then contrasted its own view with the Costa judgment, which it correctly interpreted to support a view of integration as unification-as fusion of the multiple legal system "in one system only." See Corte constituzionale 5 June 1984, Spa Granital v Amministrazione delle Finanze, Judgment of Italian Constitutional Court $n$. 170/1984. The nuance seems lost in MacCormick, supra note 10, at 4 (arguing that "the European Communities ..... constitute a legal order co-ordinate with that of Member States" and that this doctrine has been "substantially affirmed and reaffirmed many times since"). For a study of how any legal systems there are within the territory of the European Union, see Julie Dickson, Towards a Theory of European Union Legal Systems, in PHILOSOPHICAL Foundations OF EUROPEAN UNION LAW (Julie Dickson \& Pavlos Eleftheriadis eds., 2012).
} 
the legitimacy conditions of its exercise. Jürgen Habermas's pouvoir constituant mixte fills in the philosophical foundation of bidimensional supremacy. ${ }^{52}$

This account posits an originally shared popular sovereignty. In their national role, citizens look upon their nation states as political sites that have already achieved a particularly high level of justice and freedom, which must be protected from threats that, in an age of globalization, come from the outside. At the same time, however, the same individuals are also members of the future European supranational polity. In that other capacity, theirs is a political project of transnationalizing collective self-rule. The national and supranational levels are neither transient nor hierarchically prioritized over the other; rather, they are co-original and co-determinate. Habermas deploys here what he takes to be the lessons of EU constitutionalism. ${ }^{53}$ Specifically, he refers to a constitutional structure that is heterarchical rather than hierarchical, which lacks a supremacy clause of the type present in traditional federations, and where, as a result, neither level of government has automatic primacy over the other.

Habermas's theory of constituent power offers what are perhaps the strongest normative foundations of such a composite political structure. This model, centered on the hybrid will of an internally divided sovereign, must show that it would be at least rational for citizens in either of their capacity to partake in the constituent process in the terms the model envisions. The problem, however, is that built into pouvoir constituant mixte are a number of biases that, contrary to the model's own assumptions, end up prioritizing national over supranational interests.

The first bias is that of normative expectations. In this model, national citizens assume the best about what their states are and will remain, namely guarantors of a high level of justice and freedom as well as political sites that foster the production and reproduction of social solidarity. And while it is somewhat understandable why, considering the model's specifications, national citizens would have misgivings about the EU, far less understandable is why citizens in their capacity as citizens of the to-be EU relate to their EU, their own political construct, with similar misgivings. Even under the idealized conditions of a constituent moment, where one would expect the supranational sovereign to be fully invested in the political creation at hand, Habermas's model gives priority to the status quo of a Europe of nation states. To the extent the asymmetry reflects a categorical difference in nature between domestic and supranational polities, such difference is at odds with the presumption in pouvoir constituant mixte of equality between the co-original sovereigns.

The second bias is one of function. Nation-states are theorized as political sites that institutionalize a particularly advanced conception of liberal justice. This is a conception, deeply shaped by an equally strong commitment to freedom and equality, in which freedom cannot be "purchased with another's oppression." ${ }^{54}$ By contrast to this advanced understanding of the normative imperatives, the functions of the EU are ancillary. Supranational institutions enable coordination functions that allows member states to protect their thick normative commitments amid the challenges of globalization, digitalization and privatization. Their function is not to replicate on a higher level or advance the cause of human emancipation. Rather, it is a function of facilitating and protecting the learning processes and normative accomplishments that take place within member states. To be sure, Habermas leaves open the possibility that the functions of the supranational polity can evolve in time. But the normative interface between national and supranational

\footnotetext{
${ }^{52}$ JÜrgen Habermas, The Crisis of the European Union: A Response (2012); Jürgen Habermas, Citizen and State Equality in a Supranational Political Community: Degressive Proportionality and the Pouvoir Constituant Mixte, 55 J. COMmon MKT. STUd. 171, 173 (2017). I discuss this at greater length in Vlad Perju, The asymmetries of pouvoir constituant mixte, 25 EUR. L.J. 515 (2019) and Vlad Perju, Double Sovereignty in Europe? A Critique of Habermas' Defense of the NationState, 53 Tex. INT'L L.J. 49 (2018). I thank Matthias Goldmann for his comments on this section.

${ }^{53}$ As Jürgen Habermas once advised in this context, "we need only to draw the correct conclusions from the unprecedented development of European law over the past half-century." JÜrgen Habermas, The Crisis of the EuropeAn UNION: A DEBATE x (2013).

${ }^{54}$ JÜrgen Habermas, Between Facts AND Norms 418 (1998).
} 
levels of government makes such a development highly unlikely. That is the lesson of ultra vires challenges, Karlsruhe-style, from Maastricht to PSPP. Structural asymmetries make it impossible for supranational institutions to counteract effectively when member states invoke their role as primary or original guarantors of normative commitments - freedom, equality, solidarity-in order to resist supranational transfer of sectorial regulatory capabilities. None of this is to suggest that Habermas supports PSPP or the line of cases on which it rests. In fact, he is opposed to the principle of conferral, which becomes a tool for hardening the limits on the supranational transfer of sovereign rights. But it is also true that the logic of conferral is buried deep within the structural asymmetries of pouvoir constituant mixte. Just as one cannot defend Kant's federation of states merely by invoking his ultimate goal of perpetual peace, so here pouvoir constituant mixte cannot be defended on the ground that Habermas's aim is the transnationalization of democracy. Final aims are not the main issue here. Rather, the real question here is whether pouvoir constituant mixte delivers on that aim. It does not, I argue, because its fails its own normative specifications. When the allocation of functions between the national (original functions) and supranational (derivative functions) hardens, the imbalance created reflects a structural rule of hierarchy in the resolution of disputes. That rule upsets the requirement of mixed constituent power regarding the symmetry between the supposedly equal constitution-building subjects.

Consider, for instance, the impact of this allocation of functions on the welfare state. Policies creating core educational opportunities and social welfare safeguards have given political rights their fair value and have mitigated class conflicts. "Who, if not nation-states," Habermas asks, "would guarantee equal rights for all citizens in their territories." 55 EU institutions, by contrast, can hardly recreate the conditions of trust and solidarity on which the traditional welfare states depended. Their ancillary functions make their role at best one of protecting such processes at the national level. Markets must be held in check so that collective processes of will formation can be effective and meaningful. According to this unbalanced idealization, member states are sites of thick solidarity that enable not only material redistribution but the sharing and reproduction of social meaning whereas the EU is a vast territory of greater social heterogeneity and plurality of traditions, histories and cultures. As an effect of this imbalance, supranational institutions have neither the capacity nor the mandate to create the political and social conditions that could foster transnational solidarity. But the lack of such solidarity cannot then be invoked as an argument against the democratic nature of the EU. The real problem is that the institutions necessary to create the conditions in which such solidarity can be created have simply not been put in place. Establishing such supranational mechanisms is not a matter of luck. It is, rather, an ambitious political project. Such a process is inevitably ill-fated if it proceeds from asymmetrical starting points that give member states a ground on which to resist reforms to strengthen supranational institutions that they perceive, righty or wrongly, as threats to the mechanisms of national solidarity and democratic will formation.

Like the constitutional theory it seeks to ground, pouvoir constituant mixte is not only wrong. It is wrongheaded. It misdirects scarce philosophical resources away from an account of supranational power, a theory of supranational legitimacy and perhaps even a European theory of justice. European integration still lacks such theoretical constructs. The irony is that pouvoir constituant mixte takes as its guide the normative accomplishments of European constitutionalism. Ultimately, and to its detriment, the theory downplays the radicalism of European law.

\section{The Fallacy of Interpretation}

Its conceptual shortcomings aside, the bidimensionality thesis claims firm empirical grounds. Few question the narrative of qualified acceptance or outright rejection in national legal orders of the absolute and unconditional supremacy of EU law. From this perspective, a judgment such as

${ }^{55}$ JÜRgen HABERMas, EUROPA: Vision UND VOTUM 518 (2007). 
PSPP, while remarkable in its rhetoric and the boldness of holding a judgment of the CJEU as ultra vires and thus non-binding, stands in a long-standing tradition that can be summoned to defend, perhaps even immunize it from criticism.

The case against bidimensionalism would be incomplete without at least opening the door for a challenge to the underlying claim to continuity of that tradition of national resistance. ${ }^{56}$ The bidimensional thesis, given its necessitarian claim, depends on the strength of the continuity model. Taking on the empirical case is a complex task and my aim here is only to sketch out the contours of such a challenge. A much-needed comprehensive study must be left for another time. By claiming that the bidimensional thesis falls prey to a fallacy of interpretation, I argue for an alternative historical interpretation that shows that tradition as less unitary and continuous. If instead of dwelling on instances of so-called national resistance one asks what national acquiescence of EU supremacy could reasonably have entailed, one finds that acceptance, rather than resistance, characterized legal dynamics before and even during the time that the strong bidimensional supremacy theory was first formulated-a full decade before the Maastricht decision of the German Constitutional Court brought that theory into prime time. ${ }^{57}$

The doctrinal case for bidimensional supremacy centers on the resistance of national apex courts to Costa and subsequent decisions that reaffirmed it. Missing from this picture is a baseline for interpreting the canonical grands arrêts as resistance. What could national acceptance of Costa and its progenies reasonably have been expected to look like, especially at the moment of first impact?

The answer turns out to be, not much different from the actual reaction. To explain, let us start with a keen awareness of the radicalism of European constitutionalism, and specifically of the unprecedented set of legal demands that the EU Treaty, as interpreted by the CJEU, made on the member states. ${ }^{58}$ The Treaty created a new legal order autonomous from both municipal law and international law, for which purpose its signatory Member States limited their sovereign rights. Unlike the case of international norms, whose implementation into domestic law depends on the mechanisms prescribed by the constitutional rules of each system, judgments regarding the effect of European norms - not just the Treaty but also secondary legislation - in domestic law are centralized at the supranational level. Further, the Treaty conferred rights on individuals, which in specific, though broadly construed, circumstances, they can enforce in national courts. ${ }^{59}$ Norms of EU law prevail over norms of national law by virtue of their pedigree and thus irrespective of where the domestic norms fit within the hierarchy of domestic norms. ${ }^{60}$ National judges are under a duty to give effect to the primacy of EU law by setting aside or dis-applying norms of municipal law that violate a valid EU norm even, as it was generally the case, they lacked such power under national law. ${ }^{61}$ This secondary rule of conflict applies not only in a clash between national constitutions and the EU Treaty, but also between the former and ordinary legislation enacted by the European supranational political institutions. ${ }^{62}$ Because the Treaty constitutes an independent source of law, the CJEU anointed itself with the power to issue authoritative interpretations of its meaning as well as the jurisdiction to hear all challenges to the validity of EU norms under

\footnotetext{
${ }^{56}$ See Walker, supra note 30.

${ }^{57}$ See Joseph Weiler, The Community System: The Dual Character of Supranationalism, 1 YeArbook EuR. L. 267 (1981).

${ }^{58}$ See Pierre Pescatore, The Law of Integration 43 (1974) (describing European integration as a process that "undermines categories of thought which have been settled for centuries, overturns deeply-rooted political ideologies and strikes at powerfully organized interests"). See also Julio Baquero CruZ, What's LeFt of THE LAW OF INTEGRATION?: DECAY AND Resistance IN EUROPEAN Union LaW (2018).

${ }^{59}$ ECJ, Case C-26/62, NV Algemene Transport- en Expeditie Onderneming van Gend \& Loos v. Neth. Inland Rev. Admin., ECLI:EU:C:1963:1, Judgment of Feb. 5, 196]; ECJ, Case 43/75, Defrenne v. Sabena, ECLI:EU:C:1976:56, Judgement of Apr. 8, 1976 (interpreting the conditions of direct effect broadly).

${ }^{60}$ Costa, supra note 4.

${ }^{61}$ ECJ, Case-C 106/77, Amministrazione delle Finanze v. Simmenthal SpA, ECLI:EU:C:1978:49, Judgement of Mar. 9, 1978. ${ }^{62} I d$.
} 
the Treaty, including the exclusive power to invalidate them in the case of conflict. ${ }^{63}$ While the CJEU does not itself decide cases arising under national law, national courts, acting as courts of EU law and immunized from retaliatory action by the higher national courts on that basis, are under an obligation to enforce the effectiveness of EU norms and to send preliminary references to the CJEU whenever the meaning of the said norms is contested and unclear.

Assume now the perspective of national apex courts at the receiving end of this set of doctrines. What options are there, reasonably speaking, for responding to these claims? Even when the national judges submitted themselves to these unprecedented demands, as they often did, could they realistically have done it by uttering a straightforward and unconditional "we acquiesce"? Did they have the option to set aside their respective jurisprudential, political and cultural traditions, to ignore ongoing internal debates and doctrinal developments, to block off their many audiences? ${ }^{64}$ The answer is an obvious no. And if blind submission to demands of such magnitude could not possibly have been in the cards, then what was?

In any plausible scenario, the alignment between national law and the demands of the Treaty would have likely been, at least at the moment of impact, intricate and difficult rather than straightforward. It would have required working out some special mechanisms for processing the doctrines of the CJEU, especially with regard to the all-important claims to autonomy and supremacy. Therefore, pointing out references to national constitutions, rather than Costa and the Treaty itself, as evidence that national courts accepted only a qualified and conditional EU supremacy is a striking instance of interpretative puritanism. ${ }^{65}$ While Costa-based national reception did sometimes occur, ${ }^{66}$ national apex courts, as final interpreters of their respective constitutions, could hardly have been expected to disregard their own constitutions and accept demands as consequential as Costa's with no reference to the specific provisions of national constitutions. ${ }^{67}$

If one is inclined to dismiss the above matters as purely law-in-the-books matters, it might help to recall that the evidence from law-in-action is at best mixed. The empirical case for bidimensional supremacy is almost exclusively reliant on a few, high-profile judgments of national apex or constitutional courts. But such judgments may not be reliable indicators of the positions of lower courts. What was once said of the influence of Cohn-Bendit in lower French courts, that it "is still displayed on the wall only as a matter of form, much like president Mao's portrait in China, while

\footnotetext{
${ }^{63}$ ECJ, Case C-314/85, Firma Foto-Frost v. Hauptzollamt Lübeck-Ost, ECLI:EU:C:1987:452, Judgement of Oct. $22,1987$. For an earlier holding, see ECJ, Case 48/71, Commission v. Italy, ECLI:EU:C:1972:65, Judgement of July 13, 1972 para. 9 (holding that the Treaty was law of the kind that "no provision whatsoever of national law may be invoked to override [the] limitation of [states' sovereign rights].").

${ }^{64}$ For a similar view, see Gerhard Bebr, How Supreme is Community Law in the National Courts?, 11 COMMON MKT. L. REv. 3, 7 (1974) (arguing that national courts "apply Community Law within the context of their respective constitutional structure and practice influenced and formed by principles, legal thoughts and tradition which differ from one Member State to another [...]. Particularly in the early years of the operation of the Community it is hardly surprising that municipal courts viewed this relation through biased glasses, colored by their traditional constitutional experience and practice.").

${ }^{65}$ See, e.g., Paul Craig \& Gráinne de Búrca, EU law: Texts, Cases and Materials 278-303 (5 ${ }^{\text {th }}$ ed., 2015).

${ }^{66}$ See, e.g., Jörg Gerkrath, The Figure of Constitutional Law of the 'Integrated State': The Case of the Grand Duchy of Luxembourg, 10 Eur. Const. L. ReV. 109 (2014). For an argument to that effect, see also the submission of Procureur General Ganshof van der Meersch in the 1971 Etat Belge v. S.A. Fromagerie Franco-Suisse Le Ski before the Belgian Cour de Cassation: "Community law is a specific and autonomous law which is binding on the courts of member-states and makes it impossible to set against any domestic law whatsoever. The very nature of the legal system instituted by the Treaty of Rome endows the primacy with its own foundation, independently of the constitutional provisions in the states.", at 90 (English translation available in the 1993 INTERNATIONAL LAW REPORTS (1993)).

${ }^{67}$ See Marta Cartabia, The Italian Constitutional Court and the Relationship between the Italian Legal System and the European Community, 12 Mich. J. INT'L L. 173 (1990) (discussing Article 11 of the 1949 Italian Constitution, which was used as a basis for integration into the European legal order, even though the scope of that provision was Italy's membership into the United Nations, and not the European Communities).
} 
a smiling apparatchik invites you with a wink not to take this old thing too seriously," 68 should serve as cautionary tale for over-reliance on apex courts. Caution is doubly important given the ways in which European constitutionalism unsettles domestic judicial hierarchies by empowering lower courts and immunizing them from the actions of hierarchical superiors. ${ }^{69}$ For instance, the evidence is mixed on how lower courts handled the legal basis of supremacy-Treaty vs. national constitution - in the specific jurisdictions where the national apex courts chose the latter grounds to establish the "primacy by virtue of constitutional empowerment"70 of EU law. Evidence from the first decades of European integration provides support both of national courts falling into line with their national apex courts, as well as evidence of ordinary courts departing from the directives of their hierarchical superiors.

The perspective from compliance is not particularly illuminating either. The difficulty is only partly one of available indicators and the complexities of enforcement mechanisms. Leafing through the Commission's annual compliance reports, counting Francovich actions in national courts, the initiation of infringement procedures, preliminary references and proper implementation of Luxembourg's answers by referring courts provide at best a partial picture. ${ }^{71}$ Better data, while of course important, will not bring full clarity to these issues, which have a significant interpretative component. ${ }^{72}$

\section{Contextualizing PPSP}

The PSPP judgment draws legitimacy from a tradition that defines itself by placing democratic self-determination front and center in the relation between the German and the European legal orders. It claims to protect the "right of citizens to be subjected only to such public authority as they can legitimate and influence" 73 through closely monitoring limits on conferral of sovereign powers to the supranational level. EU institutions may not invoke the "finality of the integration agenda"74 to expand their competences. Interestingly, however, the German jurists do not take

\footnotetext{
${ }^{68}$ Jean Turot, Défault de transposition d'une directive communautaire de choix des armes: la pique or la masse?, REV. JURISP. FISC. 864 (1992), cited in Rosande Mehdi, French Supreme Courts and European Union Law: Between Historical Compromise and Accepted Loyalty, 48 Common MкT. L. ReV. 439, 440 (2012).

${ }^{69}$ See Karen Alter, The European Court's Political Power (1996).

${ }^{70}$ Lisbon Judgement, supra note 19.

${ }^{71}$ Studies put imperfect compliance during the early period to under $5 \%$ of all preliminary references, S.A. Nyikos, Strategic interaction among courts within the preliminary reference process-stage 1: national court preemptive opinions, 45 EUR. J. POL. RES. 527 (2006) (showing in a study of 300 preliminary reference cases from 1961 to 1994 that 96 per cent of the sample were properly implemented). Other studies put that figure even lower. Andreas Hofmann, Resistance against the CJEU of the European Union, 14 INT'L J. LAW IN CONTEXT 258 (2018) (detecting non-compliance in 4 percent of preliminary references). The number is about double with regard to the implementation of infringement judgments in the period before the Treaty had strengthened financial sanctions in such proceedings. Id. (showing that, from 1983 to 1991, the Commission referred thirtyfour cases to the CJEU for national authorities' failure to implement a judgment, which amounted to about 12 percent of all infringement judgments in that period). To be sure, there are many cases involving EU law before national courts where no preliminary references were sent. Denise Caroline Hubner, The National Decisions Database (Dec.Nat.): Introducing a Database on National Courts' interaction with European Law, 17 EUR. UNION PoL. 324-339 (2016).

${ }^{72}$ To take one example, is the refusal of a national appeals court to quash a lower court's order for a preliminary reference evidence of compliance with EU law or with national constitutional law - or both, or neither? The particular interpretation influences the conceptualization of conflict in the EU. The bidimensional thesis suggests that constitutional conflict is rare. Most of the time, national and European judges engage in a complex choreography of conflict avoidance through the doctrines and practices of mutual accommodation and toleration. But the example of preliminary references leaves open the possibility that conflict may be, in reality, much more common. The routine practice in EU constitutionalism is, in that case, not one of conflict avoidance but rather one of conflict occurrence and swift resolution.

${ }^{73}$ PSPP at para. 99 (the principle of democratic legitimation "prohibits subjecting citizens to a political authority they cannot escape and in regard to which they cannot in principle influence, on free and equal terms, decisions on the persons in power or on substantive issues.").

${ }^{74}$ PSPP at para. 101.
} 
issue with teleology as such. After all, the interpretation of conferral in light of an underlying principle of national democratic self-government is also a form of teleological interpretation. Rather, the objection is specifically to the teleology of European integration. That ultimate aim is seen, at least in this post-Maastricht interpretation ${ }^{75}$, as a threat to the project of selfgovernment of the German people and German statehood. ${ }^{76}$ The Basic Law responds to this danger by imposing duties on state agents to enforce conferral, particularly when public authority is exercised by an EU institution with weak credentials of democratic legitimation. ${ }^{77}$ As the Federal Constitutional Court interprets these duties in the context of the PSPP, "[w]here fundamental interests of the member states are affected, as is generally the case in interpreting the competences conferred upon the European Union as such and its democratically legitimated European integration agenda, judicial review may not simply accept positions asserted by the ECB without close scrutiny." 78

One might feel tempted to celebrate this defense of accountability, transparency, and responsibility. And one might perhaps even see reason to admire the German court's conviction in standing up for these core values of constitutionalism. For when review by another court-say, the CJEU - simply accepts the assertions of the ECB, then Karlsruhe will, if attempts to heighten scrutiny fail, deem the judgment of that court non-binding as ultra vires and thus unlawful. ${ }^{79}$ Here, then, is the grand spectacle of a national constitutional court willing to go all the way to defend the rule of law. Fiat justitia et pereat mundus.

Justitia? If so, this would be an exceedingly strange understanding of what justice requires. The legal perspective from which the German court undertakes this additional layer of review is, at least in PSPP, strikingly reductionist and mononuclear. If anything, it provides a textbook illustration of limitations inherent in exclusively national standpoints. Far from a perspective infused with the spirit of constitutional accommodation and tolerance, the German perspective declines all invitations to internalize the existence of other legal perspectives on a standpoint equal to one's own. Consider, for instance, how the German court uses proportionality to weaponize (constitutional) legal traditions and method of interpretation common to the Member States. Disregarding longstanding EU constitutional doctrine and practice, the court demands that the German particular structure of proportionality be deployed in order to distinguish between monetary and economic policy and thus assess the competencies of the European Central Bank (ECB). It deems the method used by the CJEU not only different from its own, but "meaningless" 80 and making the European court's judgment "simply not comprehensive and thus objectively arbitrary." 11 The broader implications are stark. What would happen if each national legal order were to see itself on a pedestal, and become a primus inter pares in the larger EU context ${ }^{22}$ It is easily conceivable how other national apex courts, acting cautiously but on grounds it deems to be fully principled, could hold a judgment of the CJEU lawless for "manifestly disregarding" 83 some other principle or tradition. The legal analysis would result in leaving the CJEU judgment effectless as ultra vires.

\footnotetext{
${ }^{75}$ The extensive and bold usage of implied powers by EU institutions before Maastricht did not trigger concerns of the German Federal Constitutional Court similar in magnitude. For an overview, see Theodore Konstadinidis, Competences of the Union, in OXFord Principles of European Union LAW (Robert Schutze \& Takis Tridimas eds., 2018).

${ }^{76}$ Ernst-Wolfgang Böckenförde, The Future of Political Autonomy: Democracy and Statehood in a Time of Globalization, Europeanization, and Individualization, in Constitutional and Political Theory: Selected Writings (Mirjam Künkler \& Tine Stein eds., 2017).

${ }^{77}$ PSPP at para. 108

${ }^{78} I$. at para. 142 .

${ }^{79}$ The German court held that the CJEU breached its own mandate under the Art 19 (1) EU Treaty to observe the law. See Id. at para. 112 .

${ }^{80} P S P P$ at para. 127.

${ }^{81} P S P P$ at para. 118 .

${ }^{82}$ These were also the concerns of the three dissenting judges in Solange I, for whom the attitude of the majority in that case with respect to European integration they labelled as "inadmissible trespass." Solange $I$ at 271.

${ }^{83}$ PSPP at para. 112 .
} 
The real consequence here would be a unilateral treaty opt-out of the member state of precisely the same kind that the German judges feared in what they saw as the implications of the EU expanding its competencies through a lax and self-serving interpretation of the principle of conferral. Each such instance ends up holding hostage all the other member states-and thus breaching the fundamental principle of equality.

This fragmentation of EU law is hardly unpredictable. In fact, EU supranational supremacy seeks precisely to address this danger. The point of insisting on hierarchical structure is not only, and perhaps not even primarily, to recognize supremacy for its own sake. It is, rather, to equalize relations of authority among national legal orders qua parts of the integrated supranational perspective. ${ }^{84}$ Exactly the same principle and underlying rationality are at work elsewhere, such as in the methodology of European interpretation. The reason why EU law purposely downplays open comparative references is to avoid normative disequilibria of precisely the kind that PSPP weaponizes. ${ }^{85}$ Similarly, the CJEU's adamant refusal to credit the national origins of specific doctrines and insist, however improbably, on the autonomous nature of their supranational versions is another case in point.

Far from having roots as deep as EU integration itself, $P S P P$ reflects a particular political project in the form it took at a specific moment in time. That project resurrected a tradition of identitarian legalism, which, while deeply embedded in German constitutional thought, had been by and large contained during the four decades following the end of World War II. It then re-emerged around the time of the creation of the post-reunification Berlin Republic. As the Cold War came to an end and the stars of history seemed aligned to support the bold vision of integration as unification or fusion that had driven Europe's constitutional project up to that moment, the new age made a push for a more limited vision of European integration as mere coordination. ${ }^{86}$ The Maastricht decision was the critical moment of inflection, when a strategy against supranational unification based on Solange-type half-measures gave way to mechanisms of national constitutional protection designed to be as radical as the vision it opposed. ${ }^{87}$ Maastricht made a double move: First, it reversed the recognition of the autonomy of the European legal order ${ }^{88}$ and, second, it made self-government the main battlefield for national resistance. While in retrospect highly successful, this turn was not inevitable. It was, rather, the constitutional expression of a project, supported by the confluence of broad and otherwise heterogenous political interests, that sought to marshal significant theoretical and practical resources with the aim to strengthen nation states as distinct political units whose viability came under the formidable challenge of bold and

\footnotetext{
${ }^{84}$ See Federico Fabbrini, After the OMT Case: The Supremacy of EU Law as the Guarantee of the Equality of the Member States, 16 GERMAN L.J. 16 (2015). In its PSPP press release, the CJEU calls it, understandably, "the only way of ensuring the equality of Member States in the Union they created." Press Release, supra note 7.

${ }^{85}$ PSPP at para 112 (accusing the CJEU that it has "manifestly disregarded" the (constitutional) legal traditions common to the Member, the traditional European methods of interpretation or, more broadly, the general legal principles that are common to the laws of Member States).

${ }^{86}$ Federico Mancini's wise and largely unheeded warning about European statehood is useful to recall in this context. Federico Mancini, Europe: The Case for Statehood, 4 EUR. L.J. 29, 31 (1998) ("the closer the Union moves towards statehood, the greater the resistance to the attainment of this goal becomes.").

${ }^{87}$ I discuss this at greater length in Vlad Perju, On Uses and Misuses of Human Rights in EU Constitutionalism, in HUMAN Rights, Legitimacy AND a World IN Disorder 263-295 (Silja Vöneky \& Gerald L. Neuman eds., 2018).

${ }^{88}$ By recognizing the autonomy of EU law, Solange I marked a "real turning point" in the trajectory of European integration. See Bebr, supra note 64, at 34. I interpret Solange II as standing alongside Solange I on the issue of autonomy of EU law. See Perju, supra note 87. It is thus the Maastricht decision that shattered this understanding by imposing an international framework on the EU: "Germany is therefore maintaining its status as a sovereign State in its own right as well as the status of sovereign equality with other States in the sense of Art. 2, sub-para 1 of the UN Charter of 26 June, 1945." Maastricht Judgment, supra note 18, at 21. Christian Calliess calls it "almost tragic" that, in adopting an international law perspective, "the court is adopting a restrictive democratic approach towards the very organization which—contrary to classic institutional organizations like the UN and the WTO_-actually has a parliament that is directly elected by its citizens and has far-reaching decision-making and control powers." Christian Calliess, The Future of the Eurozone and the Role of the German Federal Constitutional Court, 31 YeARBOOK OF EU LAW 402, 406 (2012).
} 
full-speed supranational integration. Since Germany gave this new era its central jurisprudential foundations and vocabulary, starting with the Maastricht decision of the Federal Constitutional Court, it seems only fitting that it should also provide, albeit after some fierce competition over the past decade from the autocrats in Hungary and Poland, its culmination in the PSPP judgment.

\section{Conclusion}

In the aftermath of PSPP, questions and predictions abound. Will the Federal Constitutional Court back away and accept that the CJEU proportionality analysis does not warrant depriving the judgment of legal effect in Germany? Will the economic effect of the judgment, if allowed to stand, be significant? Will it affect the far greater package of economic assistance in response to the ongoing coronavirus pandemic? Will the apex courts of some of the Eastern lands, now under the political control of their authoritarian leaders, use PSPP as constitutional arson?

All these questions are, of course, very important. But equally important is to use this opportunity to reflect on the fundamentals of EU constitutionalism. I offered here a critique of the dominant approach that sees the supremacy of EU as necessarily bidimensional. This approach is untenable as it falls prey to four fallacies: the fallacy of symmetry, through the assumption that the national and supranational legal perspectives are symmetrically positioned and similar in nature; the fallacy of selection, through which the bidimensional thesis claims an objective standpoint on supremacy of exactly the kind it denies to the exclusively national or the exclusively supranational perspectives; third, the fallacy of construction, riddled with biases between the national and supranational dimensions of a supposedly hybrid will of an internally divided European sovereign, and, finally, the fallacy of interpretation, through the empirical support of bidimensionalism is assumed to be far stronger than in fact it is. I contrasted a model that posits continuity in the national rejection of the EU claims to absolute and unconditional supremacy to one that shows the discontinuities of that reception. Discontinuity undermines the case for supremacy as necessarily bidimensional. It leaves challenges to the supremacy of EU law in venues such as PSPP without the aura of legitimacy that the judgments of national courts would have had, were they to stand on equal footing with the doctrines of the CJEU.

The claim that EU law has supremacy does not immunize CJEU judgments from the robust critique they often richly deserve. Criticism of all acts of authority, including court judgments, is an essential component of the public culture of a constitutional democracy. National judges should be participants in that process. But what national judges cannot have is a veto over the legality of the EU law. Making the legality of EU constitutionalism depend on the constant alignment of interests of a large number of national veto holders is just a roundabout way of denying EU constitutionalism its legality.

As convenient as it might be to deny it, supranational supremacy is hardly compatible with a vision of integration limited to coordination of the member states. A bolder vision of integration as unification or fusion is indispensable. The encouraging news is that this is precisely the vision behind Europe's project before the turn of the post-Maastricht era. Although never fully theorized, it remains the vision deep within many of the actual doctrines of EU constitutionalism, including autonomy and supremacy. A return to that vision requires EU constitutionalism to offer a robust answer to challenges to its authority mounted by national courts. Rejecting bidimensional supremacy is a good place to start.

Cite this article: Perju V (2020). Against Bidimensional Supremacy in EU Constitutionalism. German Law Journal 21, 1006-1022. https://doi.org/10.1017/glj.2020.59 